YEARBOOK

of ANTITRUST

and REGULATORY

STUDIES

www.yars.wz.uw.edu.pl
Peer-reviewed scientific periodical, focusing on legal and economic issues of antitrust and regulation.

Creative Commons Attribution-No Derivative Works 3.0 Poland License.

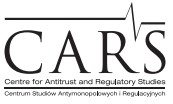

Centre for Antitrust and Regulatory Studies, University of Warsaw, Faculty of Management www.cars.wZ.uw.edu.pl

\title{
The EU 2018 Draft Directive on UTPs in B2b Food Supply Chains and the Polish 2016 Act on Combating the Unfair Use of Superior Bargaining Power in the Trade in Agricultural and Food Products
}

by

\section{Anna Piszcz}

\section{CONTENTS}

I. Introduction

II. Background

III. Aims

IV. Scope ratione personae

V. Prohibited UTPs

VI. Enforcement authority and its powers

VII. Conclusions

\section{Abstract}

The Polish Act on Counteracting the Unfair Use of Superior Bargaining Power in the Trade in Agricultural and Food Products was adopted on 15 December 2016 and entered into force on 12 July 2017. The new legal framework resembles, in some places, the legal rules contained in the 2007 Act on Competition and Consumer Protection, elsewhere resembles the 1993 Act on Combating Unfair Competition. Therefore, the article reviews the new Polish provisions taking into account the previous system including the prohibition of the abuse of a dominant position and the prohibition of unfair competition. This publication is intended to point out the peculiarities that characterize the new provisions. Readers will find here an assessment of recent Polish developments and suggestions for further development of the Polish legal framework in the EU context. In particular, the

* Dr. Hab., Professor at the University of Białystok, Faculty of Law, Department of Public Economic Law; legal advisor; piszcz@uwb.edu.pl. Article received: 22 April 2018; accepted: 3 June 2018. 
review critically analyses some solutions of the 2018 EU draft Directive on unfair trading practices in business-to-business relationships in the food supply chain and shows what amendments to the Polish legal framework will be needed, if the Directive is adopted in the current version.

\section{Résumé}

La loi polonaise sur la lutte contre l'utilisation déloyale du pouvoir de négociation supérieure dans le commerce des produits agricoles et alimentaires a été adoptée le 15 décembre 2016 et est entrée en vigueur le 12 juillet 2017. Le nouveau cadre juridique ressemble, à certains endroits, aux règles juridiques contenues dans la loi de 2007 sur la concurrence et la protection des consommateurs, qui ressemble d'ailleurs à la loi de 1993 sur la lutte contre la concurrence déloyale. Par conséquent, l'article examine les nouvelles dispositions polonaises en tenant compte du système précédent, notamment l'interdiction de l'abus de position dominante et l'interdiction de la concurrence déloyale. Cette publication est censée mettre en évidence les particularités qui caractérisent les nouvelles dispositions. Les lecteurs trouveront ici une évaluation des développements récents en Pologne et des suggestions pour le développement du cadre juridique polonais dans le contexte de l'UE. En particulier l'article analyse de manière critique certaines solutions du projet de directive de l'UE de 2018 sur les pratiques commerciales déloyales dans les relations interentreprises au sein de la chaîne d'approvisionnement alimentaire et indique quelles modifications dans le cadre juridique polonais seront nécessaires si la directive soit adoptée dans la version actuelle.

Key words: superior bargaining power; unfair use of superior bargaining power; trade in agricultural and food products; agricultural and food sector; public enforcement; private enforcement; enforcement authority; national competition authority; unfair trading practices; UTPs; business-to-business relationships; food supply chain; B2b food supply chain; small and medium-sized entrepreneurs; small and medium-sized enterprises; SMEs; suppliers; producers; producer organisations; associations of producer organisations; non-SMEs; buyers; 'one-sided' protection

JEL: K21, K23, Q18

\section{Introduction}

The objective and purpose of this study is to provide an overview of existing Polish provisions on counteracting the unfair use of superior bargaining power in the trade in agricultural and food products with a focus on a similar legislative initiative in the EU. The aim of this research is to critically analyse 
both: the solutions applied by the Polish legislation (taking into account the previous system including the prohibition of the abuse of a dominant position and the prohibition of unfair competition as a background) and the 2018 draft Directive of the European Parliament and of the Council on unfair trading practices in business-to-business relationships in the food supply chain (hereinafter, the draft Directive). ${ }^{1}$ From the research aim the following questions emerge as being essential to achieving the research aim: What are the peculiarities that characterize the new provisions? What are the results of the assessment of recent Polish developments? What suggestions for further development of the Polish legal framework in the EU context can be formulated? What amendments to the Polish legal framework will be needed, if the draft Directive is adopted in the version published so far? The point of the analysis is both normative and descriptive. The comparative method is used, as the analysis of the Polish legal framework can benefit from being examined in the light of the solutions provided for in the draft Directive.

\section{Background}

The Polish Act on Counteracting the Unfair Use of Superior Bargaining Power in the Trade in Agricultural and Food Products ${ }^{2}$ (the Anti-Power Act, ${ }^{3}$ hereinafter, the APA), submitted by the government to the lower chamber of the Parliament (Sejm) on 25 July 2016, was adopted on 15 December 2016. But it was not the first time an attempt has been made to introduce a specific legal framework for business-to-business (B2b) relationships in the food supply chain in Poland.

Already 14 months before the governmental submission, a group of deputies of the Polish People's Party submitted to the Sejm a draft Act on Combating the Unfair Market Practices of Entrepreneurs Conducting the Trade in Agricultural and Food Products against the Suppliers of Those Products. ${ }^{4}$ Not without grounds, this first draft Act of 2015 was heavily criticised by, among others, the Supreme Court, ${ }^{5}$ the Bureau of Research of

1 COM(2018) 173 final, 2018/0082 (COD).

2 Act of 15 December 2016 on Counteracting the Unfair Use of Superior Bargaining Power in the Trade in Agricultural and Food Products (Journal of Laws of the Republic of Poland 2017, item 67).

3 In Polish tzw. ustawa antyprzewagowa.

${ }^{4}$ In Polish at: http://www.sejm.gov.pl/Sejm7.nsf/PrzebiegProc.xsp?id=5E943389896EAE2 5C1257E7B004BA7C2 (all Internet references in this article were last visited on 12.04.2018).

5 In Polish at: http://orka.sejm.gov.pl/Druki7ka.nsf/0/D27AD4461235FAF3C1257E99004A C099/\%24File/3604-004.pdf. 
the $\operatorname{Sejm}^{6}$ as well as commentators (Affre and Skołubowicz, 2015) for being incompatible with the constitutional principles of the freedom of economic activity, proportionality and equality. The proposed provisions were imprecise and did not meet the requirements of correct legislation. Furthermore, they endowed some terms with a new meaning, differing from the usual one. The new legislation was to be publicly enforced by the President of the Office of Competition and Consumer Protection (in Polish Prezes Urzędu Ochrony Konkurencji i Konsumentów, hereinafter, the UOKiK President) - as the competent administrative authority - on the basis of complaints. The vacatio legis proposed for the new legislation was 30 days. Having been submitted to the Sejm only a few months before parliamentary elections, the draft Act might have been driven by political considerations. However, the Polish Parliament is subject to the principle of discontinuation, which leads to the result that a bill submitted to the previous Parliament is not decided on by the new one. As of 11 November 2015, the $7^{\text {th }}$ term of the Polish Parliament has ended and its legislative works, including works on the above-mentioned draft Act, were discontinued.

The next draft Act (draft APA) submitted by the government on 25 July 2016 was, in general, free of the aforementioned problems and was passed into law. The APA resembled in some places the legal rules contained in the 2007 Act on Competition and Consumer Protection (the Anti-Monopoly Act, hereinafter, the AMA), ${ }^{7}$ elsewhere resembled the 1993 Act on Combating Unfair Competition (hereinafter, the ACUC). ${ }^{8}$ After a 6-months vacatio legis, the APA came into force on 12 July 2017. Only as a digression, it can be seen that the APA is one of the examples of the 'publicisation' of civil (private) matters (the transfer of competences from civil justice to public administration in Poland), more precisely its form consisting of adding legal bases for public enforcement to already existing legal bases for private enforcement, which then results in a dual enforcement system (Piszcz, 2018). ${ }^{9}$

${ }^{6}$ In Polish at: http://orka.sejm.gov.pl/rexdomk7.nsf/Opdodr?OpenPage\&nr=3604.

7 Act of 16 February 2007 on Competition and Consumer Protection (consolidated text Journal of Laws of the Republic of Poland 2017, item 229 as amended).

8 Act of 16 April 1993 on Combating Unfair Competition (consolidated text Journal of Laws of the Republic of Poland 2018, item 419).

9 The remaining two forms are: (1) 'de-privatisation' of civil (private) cases, i.e. the legislature moves them from civil proceedings to administrative proceedings (non-dual system of enforcement), e.g. the abstract control of standard forms of agreements concluded with consumers was moved to competences of the UOKiK President from the Court of Competition and Consumer Protection in 2016; (2) de facto 'publicisation' taking place where, in a dual system of enforcement, private enforcement is, in fact, poor (empowered persons are usually passive even though this results in the lack of compensation) and a public enforcer tends to place an obligation on an infringer to pay to those injured a so-called 'public compensation' 
The UOKiK President, as a competent administrative authority, conducted 12 preliminary proceedings within the first three months of the application of the APA (UOKiK, 2017). On 5 March 2018, the first decision was adopted by the UOKiK President. ${ }^{10}$

The chronology described above can be related to works conducted by EU institutions with regard to unfair trading practices (UTPs) in B2b food supply chains (more: Di Marcantonio and Ciaian, 2017; Renda et al., 2014). In this context, the EU Commission's works started with its Green Paper on unfair trading practices in the business-to-business food and non-food supply chain. ${ }^{11}$ The Green Paper was published on 31 January 2013 and signalled the launch of a three-month long public consultation to gather information from interested parties. Next, in July 2014, the Commission released a communication titled 'Tackling unfair practices in the B2B food supply chain' ${ }^{12}$ encouraging Member States to look for ways to improve protection of small food producers and retailers against the unfair practices of their sometimes much stronger trading partners. The first Polish draft Act of 2015 could have been considered to be inspired by the Commission's communication, albeit the 2-page explanatory notes accompanying the draft Act do not mention EU works at all.

The next EU document, 'Report from the Commission to the European Parliament and the Council on unfair business-to-business trading practices in the food supply chain' of 29 January $2016,{ }^{13}$ referred to in its explanatory notes to the Polish APA (performing a largely justificatory function). ${ }^{14}$ The Commission concluded therein that at this stage there was no need for EU legislative measures in the field of UTPs. The Commission's took this view based on the idea that operators in the supply chains should participate in voluntary schemes designed to reduce UTPs, and Member States should provide effective and independent enforcement at national level. So, regulatory initiatives in the discussed field were left to Member States. In Poland, the manifestation of the above is the APA. However, within one year from the publication of the Commission's report, the European Parliament, ${ }^{15}$

(within a broader competence to impose obligations on a party to administrative proceedings), thereby becoming a 'mixed bag' of regulatory competences and the adjudicative function (it happens e.g. in cases of anti-consumer collective practices).

${ }^{10}$ Decision No. RBG-3/2018, Cykoria case. In Polish at: https://decyzje.uokik.gov.pl/bp/ dec_prez.nsf.

11 COM (2013) 37 final.

12 COM (2014) 472 final.

13 COM (2016) 32 final.

14 In Polish available at: http://www.sejm.gov.pl/Sejm8.nsf/druk.xsp?nr=790.

15 Resolution of 7 June 2016 on unfair trading practices in the food supply chain, No. P8_TA(2016)0250. 
the European Economic and Social Committee ${ }^{16}$ and the Council ${ }^{17}$ all called for actions to be taken at the EU level. Hence, the Commission prepared its proposal against UTPs in B2b food supply chains, which was preceded by an open public consultation from August to November 2017. ${ }^{18}$ The draft Directive of the European Parliament and of the Council on unfair trading practices in business-to-business relationships in the food supply chain (hereinafter, the draft Directive) was published on 12 April 2018. ${ }^{19}$

The Polish APA has been widely discussed and has come under strong criticism (Jurkowska-Gomułka, 2017; Krasnodębska-Tomkiel, 2017; Namysłowska and Piszcz, 2017; Podrecki, 2017; Sroczyński, 2017; Bolecki, 2017; Szwedziak-Bork, 2017; Roszak and Turno, 2017; Kohutek, 2017; Stawicki, 2017). When compared to corresponding provisions in the draft Directive, the fact will be discussed below that there are differences between the two, in particular in the context of the aims and the scope ratione personae of the legal frameworks, the prohibited UTPs and also powers of the enforcement authority; these issues are regulated in a different way in both systems and must contribute to the discussion.

\section{Aims}

Although before the APA there was no specific legal framework for counteracting the unfair use of superior bargaining power in Poland, those who faced such practices within the Polish territory were formally able to seek redress based on other laws available at that time. The legal bases for private enforcement could be found (and still can) in the 2013 Act on Payment Terms in Commercial Transactions, ${ }^{20}$ the 1964 Civil Code, ${ }^{21}$ as well as in the ACUC. The latter statute declares in its Article 1 that it regulates counteracting and combating unfair competition in the public interest as well as in the interests of entrepreneurs and customers. Article 3 paragraph 1

16 Opinion of 30 September 2016 on report from the Commission to the European Parliament and the Council on unfair business-to-business trading practices in the food supply chain, No. NAT/680.

17 Conclusions of 12 December 2016 on strengthening the position of farmers in the food supply chain and tackling unfair trading practices, No. 15508/16.

18 See https://ec.europa.eu/info/consultations/food-supply-chain_en.

19 COM(2018) 173 final, 2018/0082 (COD).

20 Act of 8 March 2013 on Payment Terms in Commercial Transactions (Journal of Laws of 2013, item 403, as amended).

21 Act of 23 April 1964 - Civil Code (consolidated text Journal of Laws of 2017, item 459, as amended). 
defines an act (practice) of unfair competition as an activity contrary to the law or bonos mores which threatens or infringes the interest of another entrepreneur or customer (therefore, private interest and - most of all - the one privately enforced before courts of civil law). However, those statutes, to the extent that they cover the unfair use of superior bargaining power, have de facto been considered difficult to enforce and ultimately ineffective. Weaker parties to commercial transactions have often been afraid of retaliation and/or compromising an existing commercial relationship with the stronger party, a realisation also noted by the Commission in its Explanatory Memorandum to the draft Directive, which discusses the so-called 'fear factor'. ${ }^{22}$ Owing to this, they have not been willing to seek redress before a court of civil law even till the end of the relationship. ${ }^{23}$ This has not translated into a lack of such civil cases, since from time to time, after the termination of the relationship, the weaker party has indeed pursued a so-called 'divorce case' and sought redress (even though in practice civil proceedings might have been long-lasting and expensive).

On the other hand, before the APA, public enforcement in the discussed field was available only where a specific unfair practice fell within the scope of the AMA, as a rule, as an abuse of a dominant position (Article 9 AMA). The AMA lays down the framework for the development and protection of competition and sets out the principles of the protection of interests of entrepreneurs and consumers undertaken in the public interest. The existence of this public interest has to be proven in each individual case; the review courts used to require this from the UOKiK President. ${ }^{24}$ However, unfair practices of entrepreneurs without dominant positions in a given market have been left outside the scope of the AMA and in such cases the UOKiK President was not competent to intervene.

In such circumstances, a specific, publicly enforced prohibition of the unfair use of superior bargaining power has seemed necessary. The legislature might have felt that by the APA they were filling an important lacuna within public

22 Explanatory Memorandum, p. 2, 5-6, 10.

23 Explanatory notes to the APA, supra note 12 at p. 3.

${ }^{24}$ For instance judgement of the Supreme Court of 5 June 2008, III SK 40/07, OSNP 2009, No. 19-20, item 272: 'The premise of violation of public interest is the criterion for selecting of cases undertaken by the antimonopoly authority. Decision on institution, conducting and concluding antimonopoly proceedings should indicate and describe the public interest justifying the antimonopoly intervention. (...) Violation of public interest takes place when anticompetitive behaviour affects "a wider circle of market participants" or when it resulted in the other adverse market effects'; judgement of the Supreme Court of 7 January 2010, III SK 16/08, OSNP 2010, No. 13-14, item 177: 'The public interest covers the protection of competition as a mechanism guaranteeing free entrance of undertakings to the market'. See Błachucki, 2013, p. 90. 
enforcement. Article 1 APA states that the APA lays down the rules and procedures 'in order to ensure the protection of the public interest'. However, Article 7 paragraph 2 APA considers the use of superior bargaining power unfair where it is contrary to bonos mores and threatens or infringes a vital interest of the other party. It has been pointed out in several publications that the need for the UOKiK President, as an enforcement authority, to prove and protect private interests when intervening in individual contractual relationships may, in fact, lead to situations where the UOKiK President protects the public interest to a very small extent only or that the latter barely exists in particular cases (Jurkowska-Gomułka, 2017, p. 15-19; Sroczyński, 2017, p. 657-658; Krasnodębska-Tomkiel, 2017, p. 689).

The second, closely related problem is what may in fact be included in the broad notion of 'public interest' used in Article 1 APA. Certainly, the protection of competition as understood under the AMA cannot (Jurkowska-Gomułka, 2017 , p. 15). In order to answer the question, commentators have analysed the aims of the legislation in question, as declared in the explanatory notes to the APA, which pointed to the following aims: the protection of food security (as a part of national security), the protection of food safety and quality and, thereby, the protection of its consumers. But the aims declared by the legal drafters are only one side of the story. On the other side, there is whether these aims are real and, in reality, shared by the enforcer. Interestingly, in the first and only decision adopted under the APA in the Cykoria case, ${ }^{25}$ the UOKiK President did not refer to any of the values mentioned in the explanatory notes. Drawing on the jurisprudence related to the AMA, the enforcer explained only that an infringement of the public interest occurs mainly when the activity (practice) of a given entrepreneur threatens the general interest of the society or of a wider circle of market participants. From there, this reasoning proceeded to the conclusion that in the scrutinised case the public interest manifested itself in the scale of the practices in question; adverse effects of the practices might have arisen for a wide range of addressees, including each supplier contracting with the infringer. The enforcement authority avoided confirming or denying the interpretation of the aims of the legislation authored by the legal drafters and somehow accepted by the legislature once having adopted the APA.

The above-mentioned documents were issued before the publication of the draft Directive. Are the aims of the latter met by the declared aims of Polish legislation? Keeping in mind that the Commission wants to reduce the occurrence of UTPs, and address the current situation of under-protection, one must notice that the values underpinning the draft Directive are scattered

25 Decision of 5 March 2018, No. RBG-3/2018. In Polish at: https://decyzje.uokik.gov.pl/ bp/dec_prez.nsf. 
around the text of the Commission's proposal. First, in the Explanatory Memorandum, the Commission mentions the protection of small and mediumsized suppliers in the food supply chain (insofar as they sell food products to buyers who are not small and medium-sized) ${ }^{26}$ and, thereby, 'contributing to a fair standard of living for the agricultural community, an objective of the common agricultural policy under Article 39 TFEU'. ${ }^{27}$ Second, measures at the EU level consisting of common UTP rules would aim to improve the governance of the food supply chain. ${ }^{28}$ Third, the Commission's proposal, like the Polish APA explanatory notes, touches upon food safety, however, indirectly in words: 'operators that are not subject to UTPs may be left with more economic margin to invest in producing in environmentally sustainable and climate-friendly ways and to prevent food waste, or they may feel less pressured to compensate for the lost margin by cutting corners when it comes to environmental and food safety legislation'. ${ }^{29}$ In the Legislative Financial Statement, it is declared that the objective of the Commission's proposal is to contribute to the priority of 'a deeper and fairer internal market with a strengthened industrial base', which is translated into the general objective of 'viable food production' of the Common Agricultural Policy. ${ }^{30}$ The specific objectives are: maintaining market stability, enhancing agricultural producers' income and improving agricultural competitiveness. ${ }^{31}$

The two sets of values (interests) protected hardly overlap, a fact that can be seen in the Table 1 .

The Commission admitted that the aim of its proposal is to protect interests of some market operators. That is what the Polish governmental legal drafters have seemed to be afraid of; perhaps it was very hard for them to reconcile, in principle, private interests of some market operators with the public interest under the 'roof' of UOKiK, which is responsible, first and foremost, for competition protection (and certainly not agricultural policy). Do the differences shown above mean that the APA will need to be amended if the draft Directive is adopted? To this question there can be but one answer - a negative one. The discussed values (interests) are contained in the APA explanatory notes. An updated set of values (interests) drawing on the Directive will not need to appear in the Act amending the APA in order to transpose the Directive into Polish laws; however, it might appear in its explanatory notes.

26 Explanatory Memorandum, p. 4.

27 Ibid, p. 4, 6. See also recital 7 of the preamble to the draft Directive.

28 Ibid, p. 1, 6.

29 Ibid, p. 11.

${ }^{30}$ Legislative Financial Statement, point 1.4.1.

31 Ibid, point 1.4.2. 
Table 1: Values (interests) protected in the Polish APA and the Commission's proposal

\begin{tabular}{|l|c|c|}
\hline \multicolumn{1}{|c|}{ Value/interest protected } & Polish APA & Commission's proposal \\
\hline Food security & YES & NO \\
\hline Food safety & YES & YES (indirectly) \\
\hline food quality & YES & NO \\
\hline Consumers & YES (indirectly) & NOT DECIDED ${ }^{32}$ \\
\hline SMEs' interests & NO & YES \\
\hline Fair standard of living, enhancing income & NO & YES \\
\hline Environment & NO & YES (indirectly) \\
\hline Deeper and fairer internal market & N/A & YES \\
\hline Viable food production & NO & YES \\
\hline Maintaining market stability & NO & YES \\
\hline Improving agricultural competitiveness & NO & YES \\
\hline Competition & NO & NO \\
\hline
\end{tabular}

Source: own study based on the Explanatory Notes to the APA and the Commission's proposal.

\section{Scope ratione personae}

The provisions on the scope ratione personae of the APA show dissimilarities from the Commission's proposal. The protection against UTPs under the APA covers both suppliers and buyers ('two-sided' protection) in B2b food supply chains (Article 1 and 6) and is not limited to small and medium-sized entrepreneurs/enterprises (SMEs). It is considerably different from the protection provided for in the draft Directive that is going to be applied in B2b food supply chains only to suppliers ('one-sided' protection) classified as SMEs and only as regards their sales to buyers which are not SMEs (Article 1(2)).

32 See the Explanatory Memorandum at p. 10-11: 'partial harmonisation of UTP rules at EU level is expected to have limited effects on consumers. In the open public consultation, operators do in general not claim that UTPs (e.g. by the SCI) lead to advantages for consumers, for example through lower consumer prices that become possible through margins that were extracted from upstream suppliers through UTPs. It is sometimes argued that consumer prices are negatively affected by below-cost-sales prohibitions, but these are not covered by the impact assessment. The consumer organisations which have reacted to the consultation encourage public UTP rules because they expect a longer-term negative effect of UTPs on consumer prices'.

33 Even though certain links to competition policy are defined. 
The preamble to the Directive and the Explanatory Memorandum clarify that the protection covers both national and foreign SME agricultural producers, including their organisations such as cooperatives, and other SME suppliers, including manufacturers, distributors and intermediaries along the food supply chain if they sell to non-SME buyers established in the EU. ${ }^{34}$

First, a technical remark needs to be made on the notion of 'small and medium-sized enterprise' (Article 2(c) of the draft Directive). Its definition refers to the definition of micro, small and medium-sized enterprises set out in the Annex to Commission Recommendation 2003/361/EC. . $^{35}$ This reference rightly results in that - contrary to the literal reading of the words defined in Article 2(c) of the draft Directive ('small and medium-sized enterprise') - microenterprises are within the scope ratione personae of the draft Directive. What raises doubts is that the EU legislature would impose on Member States a requirement to follow a non-binding act (Recommendation) via a reference to the latter made in a legally binding act (Directive), even though the necessary identical definitions are also contained in a legally binding act, namely Commission Regulation 651/2014, ${ }^{36}$ and more precisely, in Article 2 of Annex I to this Regulation. This might be corrected by national legislatures, ${ }^{37}$ but why make mistakes that can be avoided?

The scope ratione personae of the draft Directive lets us make some general anticipatory remarks regarding the potential of the EU legislation (if adopted in the proposed shape) to contribute to the protection against UTPs. First, the draft Directive does not focus at all on the period of time or the moment when the victim needs to be an SME and the infringer needs to be a nonSME. When do the staff headcount and financial requirements determining whether one falls into the SME category (in the case of the victim) and the non-SME category (in the case of the infringer) need to be met (jointly)? At any time during the UTP (pursuant to recital 11 of the draft Directive unfair trading practices may occur at any stage of the sale of a food product, that is before, during or after a sales transaction)? And later on? At a time of lodging a complaint to the enforcement authority? During the proceedings of the latter? It seems that the first solution would be the most effective. We should also bear in mind that if this is not clarified by the EU legislature, Member

34 Recitals 7-8 of the preamble to the draft Directive; Explanatory Memorandum, p. 13.

35 Commission Recommendation 2003/361/EC of 6 May 2003 concerning the definition of micro, small and medium-sized enterprises (OJ 2003 L 124, p. 36).

${ }^{36}$ Commission Regulation (EU) No. 651/2014 of 17 June 2014 declaring certain categories of aid compatible with the internal market in application of Articles 107 and 108 of the Treaty (OJ 2014 L 187, p. 1).

37 More on the definition of SMEs in EU directives and its implementation: Piszcz, 2019 (forthcoming). 
States are very unlikely to have any ambitions to add any provisions that would clarify this. It also needs to be emphasised that the data applicable to the staff headcount and financial amounts is that relating to the latest approved accounting period and calculated on an annual basis. The ex-post assessment of the SME/non-SME status may raise doubts in terms of legal certainty.

Second, faced with the limitations resulting from the draft Directive, it would be impossible to apply the Directive to the protection of buyers of food products who have weak bargaining power in B2b supply chains (compared to suppliers). Inexplicably, the Commission's proposal postpones the problem of their protection until the review of the application of the Directive provided for in Article 11..$^{38}$ In practice, the use of UTPs by suppliers occurs, even though they are not as frequent as UTPs of buyers of food products. Leaving them outside the scope of the Directive does not seem justified.

Third, UTPs of SME buyers as well as UTPs against non-SME suppliers do not fall within the scope of the draft Directive. The Commission does not seem preoccupied with the risks posed by situations where unequal bargaining powers and UTPs result from a 'relative' disproportion between the bargaining positions of the parties to a contract, and not only from a disproportion between their size measured by way of staff headcount and financial ceilings. The Explanatory Memorandum makes clear that 'the commercial relationships of large players who are less likely to be affected by UTPs or who can be expected to counter-vail undue pressure to "suffer" UTPs, and who would not be subject to the fear factor (...) in the same way as SME operators' are to fall outside the scope of the protection. ${ }^{39}$ But how is this choice of a targeted protection justified by the Commission? A targeted protection is considered 'more proportionate at this stage' and SME suppliers are 'often the ones who cannot defend themselves against UTPs due to their lack of bargaining power' ${ }^{40}$ The relevant rules should apply to business conduct by larger, non-SME, operators in the food supply chain as they are 'the ones who normally possess stronger relative bargaining power when trading with SME suppliers'. ${ }^{41}$ So, it seems that the Commission has based its choice on some dominant 'regularities' in statistics; the words 'often' and 'normally' seem to be the key words here.

The most frequent victims of UTPs deserve protection and the most frequent infringers deserve sanctions under the Directive. But those categories of entrepreneurs which are endangered by UTPs only sometimes and those who are endangered by UTPs of SMEs (e.g. the biggest medium-sized

\footnotetext{
38 See recital 19 sentence 2 in the preamble to the draft Directive.

39 Explanatory Memorandum, p. 6.

${ }^{40}$ Ibid, p. 9-10.

41 Recital 9 of the preamble to the draft Directive.
} 
entrepreneurs) are not to be protected by the Directive. This poses at least two dangers. First, it will be quite easy for some companies buying food to remodel their structures so that buyers are no longer non-SMEs (however, not beyond the mere category of 'autonomous enterprises'). The apportionment of turnover and employees may be a way to circumvent the prohibition of UTPs. There may also be a risk of pressures faced by SME suppliers to merge into bigger non-SME entities/groups. Moreover, the definition of the supplier contained in Article 2(b) of the draft Directive ('any agricultural producer or any natural or legal person, irrespective of their place of establishment, who sells food products. The term "supplier" may include a group of such agricultural producers or such natural and legal persons (...)') seems burdened with the risk of narrowing down the catalogue of factually protected entities. That is because the definition does not specify criteria for a 'group' whereas staff headcount and financial criteria of any group covered by Article 2(b) should be summed up for the purpose of the assessment of the SME status of a given entity. Are groups in the meaning of Article 2(b) only legally recognised groups or capital groups? The interpretation of this word should not go beyond them if it is not to narrow the scope of the protection.

Furthermore, the Commission expressly refers in the Explanatory Memorandum to the preventive and deterrent character of the rules established by the draft Directive. ${ }^{42}$ We should bear in mind, however, that the 'piecemeal' approach with regard to the scope ratione personae of the Directive will tend to undermine preventive and deterrent effect of the proposed regime. Therefore, the protection against UTPs should instead be defined in terms of absolute fairness considerations or a 'relative' disproportion, rather than the size of the parties to a contractual relationship.

The question arises whether Poland (as well as other Member States whose legal frameworks are characterised by the broader scope ratione personae) will be obliged to limit the scope of its national provisions. Article 1(1) of the draft Directive utilises the minimum harmonisation approach; it is related literally to a list of prohibited UTPs and rules concerning their enforcement. Article 8 allows Member States to design legislation going beyond the rules of the Directive but it defines them enumeratively as those set out in Articles 3, 5, 6 and 7 , provided that such national rules are compatible with the rules on the functioning of the internal market. Recital 10 sentence 3 of the preamble to the draft Directive guarantees more precisely that Member States should not be precluded from adopting and applying on their territory stricter national laws protecting SME suppliers and buyers against unfair trading practices occurring in business-to-business relationships in the food supply chain, subject to the

${ }^{42}$ Explanatory Notes, p. 1, 3, 5, 14. See also recital 15 of the preamble to the draft Directive. 
limits of EU law applicable to the functioning of the internal market. ${ }^{43}$ This will explicitly allow for a 'two-sided' protection, if the Member States opt for it. But the question is if Member States are able to protect - with the same set of rules - entrepreneurs having weaker bargaining power vis-a-vis their trading partners regardless of their size. The answer to this question should be in affirmative. An opposite mindset would be the antithesis of what effectiveness of protection against unfairness is supposed to be about. The EU measures are to be only complementary to measures existing in Member States and the code of conduct of the Supply Chain Initiative ${ }^{44}$ applied regardless of size. ${ }^{45}$ The only limits to the possibilities of broader protection are those of EU law applicable to the functioning of the internal market (Article 8), and it would be difficult to find EU laws that would be contrary to such broad protection. It is worth recommending, however, that this issue should be added to the Directive in an unambiguous manner, at least to its preamble before it is adopted.

The approach taken to the protection framework by the draft Directive is considerably simpler compared to the APA. Under the APA a 'superior bargaining power test', including various conditions, needs to be satisfied before a practice can be considered unfair (Article 7 paragraph 1). Superior bargaining power is such a position of the buyer toward the supplier where the supplier does not have sufficient and actual opportunities to sell agricultural or food products to other buyers, and where there is a significant disparity in economic potential between the two parties, which puts the buyer at an advantage, or such position of the supplier toward the buyer where the buyer does not have sufficient and actual opportunities to purchase agricultural or food products from other suppliers and where there is a significant disparity in economic potential between the two parties, which puts the supplier at an advantage. It can be seen that the legislature put superior bargaining power under a very restrictive test and its conditions are proving difficult to interpret (Namysłowska and Piszcz, 2017, p. 82-88; Podrecki, 2017, p. 695-698; Jurkowska-Gomułka, 2017, p. 17-18). As a result, this may be the Achilles heel for the enforcement of the APA by the UOKiK President. If the Polish legislature repeals this test while making the necessary adjustment to the scope ratione personae, this will significantly simplify the proceedings before the UOKiK President.

43 Recital 17 adds that the rules laid down in the Directive 'should not impair the possibility for the Member States to maintain existing rules that are further-reaching or to adopt such rules in the future, subject to the limits of Union law applicable to the functioning of the internal market'.

44 See http://www.supplychaininitiative.eu/.

45 Explanatory Memorandum, p. 3, 11. 
Another question is whether Member States could retain exceptions to the scope ratione personae of the prohibition of UTPs. Choosing a positive answer to this question (after the adoption of the Directive) would not be grounded. The draft Directive neither allows nor provides for any exceptions to Article 1(2). The Polish system of exceptions contained in Articles 2-3 APA consists of three types of exceptions (where the APA is not applied):

1) subjective exclusions (Article 3 APA) - they are justified by organisational 'buyer - supplier' relationships of a special type and are related to UTPs in the following relationships: (a) cooperative - its member, (b) agricultural producer group - its member, (c) member of a preliminarily recognised producer organisation for fruit and vegetables - another member thereof, (d) member of a recognised producer organisation for fruit and vegetables - another member thereof;

2) exclusion of direct supplies in the meaning of Article 1(2)(c) of the Regulation of the European Parliament and of the Council 852/2004, ${ }^{46}$ that is direct supplies, by the producer, of small quantities of primary products to the final consumer or to local retail establishments directly supplying the final consumer - Article 2 APA at the beginning (in principio);

3) de minimis rule applied if any of the following conditions is not met:

(a) the aggregate turnover between the parties in the year of commencement of the proceedings concerning the prohibited practices or in any of the 2 years preceding that year exceeds the amount of PLN 50000 (approx. EUR 12 000) - Article 2(1) APA,

(b) in the year preceding the year of commencement of the proceedings concerning the prohibited practices, the turnover of the infringer (or, in the case of the infringer being part of a capital group, the turnover of such group) exceeds the amount of PLN 100,000,000.00 (approx. EUR 24000 000) - Article 2(2) APA.

Commentators stated that those thresholds remained too small, which would result in a broader (too broad?) scope for intervention of the enforcement authority (Jurkowska-Gomułka, 2017, p. 10; Krasnodębska-Tomkiel, 2017, p. 689; Salitra, 2017, p. 132; Stawicki, 2017). Certainly, with the Directive the Commission does not try to solve the problem of potential overload of enforcement agencies with possibly the smallest cases. If the version of the draft Directive proposed so far is adopted, all the current exceptions would need to be deleted from the APA. The idea of an appropriate level to set the law-enforcement thresholds at in the Directive might be rethought, save that

46 Commission Regulation (EC) No. 852/2004 of 29 April 2004 on the hygiene of foodstuffs (OJ 2004 L 139, p. 1). 
the Commission considers the limitation of potential buyers to non-SMEs to be the only such threshold.

\section{Prohibited UTPs}

The draft Directive does not contain a general clause of UTP but it creates two minimum lists of prohibited UTPs (even though Article 1(1) declares that it establishes 'a minimum list' of prohibited UTPs). First, it lists in an enumerative way trading practices that are considered as unfair by their very nature and so deviating from them should not be subject to the parties' contractual freedom ('black list', Article 3(1)(a)-(d)). The blacklisted practices take place where:

- a buyer makes (simplifying) delayed payment;

- a buyer cancels orders of perishable food products at such short notice that a supplier cannot reasonably be expected to find an alternative to commercialise or use these products;

- a buyer unilaterally and retroactively changes the terms of the supply agreement concerning the frequency, timing or volume of the supply or delivery, the quality standards or the prices of the food products;

- a supplier pays for the wastage of food products that occurs on the buyer's premises and that is not caused by the negligence or fault of the supplier.

Additionally, the second list defines practices that are considered unfair unless agreed to in clear and unambiguous terms at the conclusion of the supply agreement ('grey list', Article 3(2)(a)-(d)). They take place where:

- a buyer returns unsold food products to a supplier;

- a buyer charges a supplier payment as a condition for the stocking, displaying or listing food products of the supplier;

- a supplier pays for the promotion of food products sold by the buyer;

- a supplier pays for the marketing of food products by the buyer.

A 'rule of reason' regulatory approach, recommended in the literature (see Sexton, 2017, p. 15), has not been adopted.

Member States are to be under the obligation to ensure that both lists constitute overriding mandatory provisions which are applicable to any situation falling within their scope, irrespective of the law otherwise applicable to the supply agreement between the parties (Article 3(4)).

An exhaustive and detailed list of prohibited practices does not exist under the Polish APA. Article 7 paragraph 2 uses a general clause whereby the use of superior bargaining power is considered unfair if it fits both of the following requirements: 
- it is contrary to bonos mores,

- it threatens or infringes a vital interest of the other party.

The exemplary list of prohibited practices (Article 7 paragraph 3 APA) contains:

- unjustified termination or threatening with the termination of a contract;

- arrangements whereby only one of the parties is entitled to dissolve, terminate or withdraw from a contract;

- making the conclusion or continuation of a contract subject to acceptance or fulfilment by the other party of other obligations which have neither substantive nor customary connection with the subject of such a contract;

- unjustified extension of payment periods for the agricultural or food products supplied.

A lot of attention has been given to these provisions in literature (Namysłowska and Piszcz, 2017, p. 91-115; Bolecki, 2017, p. 63-74; Manteuffel and Piaskowski, 2017, p. 42-45; Salitra, 2017, p. 132-136). Looking at them from the interpreter's viewpoint, commentators have criticized the general clause for its inherent vagueness (Roszak and Turno, 2017, p. 29; Manteuffel and Piaskowski, 2017; Błachucki and Jóźwiak-Górny, 2018, p. 156). Conceptually, the approach adopted in the APA is close to the one used in the ACUC (even though the third example of prohibited practices is patterned after one of the anti-competitive practices, more precisely the so-called 'tying'). Therefore, it shares properties of the latter, including the unpredictability of the general clause. It is even expected that open references may be interpreted broadly and in a rather 'aggressive' manner, that is not only in the case of really serious infringements but also to a variety of more subtle market situations (Stawicki, 2017). On the other hand, interpretations of the general clause - that has been extensively examined in a number of contexts related to combating unfair competition - may act as an inspiration for the interpreter of Article 7 APA, making the interpretation smoother.

The implementation of the Directive will not require Polish legislature to switch to a model of a legal framework that does not contain a general clause. Furthermore, a general clause may in fact involve the UTPs defined in the draft Directive, especially since Article 7 paragraph 3 APA gives only an exemplification of prohibited practices. However, we need to take into account also that the draft Directive requires Member States to protect SME suppliers against UTPs with 'overriding mandatory provisions'. This will result in adding required provisions to the APA on the protection available to SME suppliers against UTPs that are black- and grey-listed in the Directive. As already mentioned above, the Directive is going to be but a minimum harmonisation act. The main implication of this is, on the one hand, that Member States can prohibit more types of UPTs than those listed in the Directive. They can also 
introduce stricter lists of prohibited practices, for instance, they can blacklist practices that are grey-listed in the draft Directive. On the other hand, this means that many areas may be left where the legal systems of the Member States will differ quite substantially from one another with regard to the protection of entrepreneurs against UTPs.

\section{Enforcement authority and its powers}

The draft Directive takes an approach to enforcement of the prohibition of UTPs that is based on decentralisation (enforcement by Member States). Therefore, Member States are required by Article 4 of the draft Directive to designate a competent authority for the enforcement of the prohibition of UTPs. In cases where there is no legal framework at all, Member States would have to implement the new measures, including designating an enforcement authority; in cases where the legal framework does exist, they would need to make the necessary adjustments (if any), including in the design of the enforcement authority. The Commission does not dictate directly in the draft Directive that the model of enforcement has to be administrative in nature. However, once the Commission considers the practical value of relying on contract law (or self-regulatory initiatives) as limited, at the same time it expects Member States to entrust administrative authorities with the enforcement of the prohibition of UTPs (recital 6 of the preamble to the draft Directive). So, national authorities must have the power to take effective action against UTPs regardless of whether alternative remedies may be available, including under a code of conduct.

The analysis of the literal reading of Article 6 of the draft Directive leads to the conclusion that each Member State should designate one administrative authority that will investigate cases as well as take enforcement decisions concerning them (rather than an administrative authority that only carries out the investigations and then brings the cases before a court for a decision on substance and/or on a fine). The enforcement authority does not have to be a newly established one. Member States can expand the mandate of an existing authority to realise economies of scope. Interestingly, the Explanatory Memorandum submits the example of existing enforcement authorities in the area of competition law (national competition authorities; hereinafter, NCAs).$^{47}$ By the way, it is worth mentioning that UTP rules will be compatible with and complementary to EU competition rules. ${ }^{48}$

${ }^{47}$ Explanatory Memorandum, p. 14.

48 Ibid, p. 3. 
Under the Polish APA, the UOKiK President as a single administrative authority - responsible first and foremost for the protection of competition and consumers - investigates cases and adopts administrative decisions (Article 8) subject to judicial control upon an action by the alleged author of the infringement. It can be stated that an effective remedy against the decision of an enforcement authority is provided for the infringer, which is compatible with the rights of defence (in terms of Article 48 of the Charter of Fundamental Rights of the European Union). ${ }^{49}$

Choosing the UOKiK President as the authority enforcing the APA has been criticised by commentators (Jurkowska-Gomułka, 2017, p. 9-18; Krasnodębska-Tomkiel, 2017, p. 688-690). It has been pointed out that the UOKiK President is not a specialised authority and the legislature should have chosen an authority competent in agricultural policy (Jurkowska-Gomułka, 2017, p. 14-18). Concern has also been expressed that a new trend might have appeared consisting of entrusting the UOKiK President with regulatory competences in markets not covered by the competences of any other specialised authority (Krasnodębska-Tomkiel, 2017, p. 690). The Directive will provide arguments for the choice of the UOKiK President as the authority enforcing the APA.

According to recital 13 sentence 2 of the preamble and Article 5 and 6(a) of the draft Directive, the enforcement authority should be able to act either on its own initiative or by way of complaints. The Polish AMA procedural provisions were intended (to some extent at least) to be a model for the APA; the explanatory notes accompanying the APA referred to procedural competition law as a point of reference with respect to the newly introduced solutions. A distinctive 'trademark' of the enforcement of competition law in Poland is that under the AMA there are no statutory grounds for the initiation by the NCA of proceedings upon a complaint - the UOKiK President commences proceedings solely on its own initiative. Hence, the status of a party to the proceedings is reserved to those to whom the infringement is, rightly or wrongly, attributed to by the UOKiK President. An alleged victim of an infringement may notify the UOKiK President in writing of his suspicion that prohibited practices have taken place and the identity of a victim who submitted a notification is confidential. However, such a notification is not binding upon the UOKiK President (does not oblige the UOKiK President to initiate proceedings) and, in the case of ex officio initiation of proceedings, a victim who submitted a notification is not a party to the proceedings and cannot appeal against the resulting decision. A victim who submitted a notification is informed in writing about the ex officio initiation of proceedings or about insufficient grounds for such initiation; the

49 Ibid, p. 11. 
information must explain the reasons for what the UOKiK President decided to do in the case. However, a letter containing such information from the UOKiK President cannot be questioned before a court. The same approach is adopted in the APA (Article 9) which has been criticised in the literature (Jurkowska-Gomułka, 2017, p. 12).

The specificity of proceedings conducted on the basis of the APA compared to competition proceedings is, however, determined by the fact that in competition proceedings a notification may be filed by any person; by contrast, under the APA only a victim of a prohibited practice is entitled to submit such notification. The right to submit a notification has not been conferred on producer organisations or associations of producer organisations whose member(s) or member(s) of their members are affected by a prohibited practice, even though such right could have proven effective in tackling the fear factor; no wonder this approach faced criticism in literature (Jurkowska-Gomułka, 2017, p. 12). Moreover, the last solution is not in line with Article 5(2) of the draft Directive. By way of digression, the latter is faulty from the perspective of the employed legislative technique and is, in fact, redundant, since a supplier has the right to submit a complaint enshrined in Article 5(2) and, moreover, the definition of a supplier contained in Article 2(b) includes inter alia producer organisations and associations of producer organisations.

It is ambiguous how a 'complaint' should be construed for the purposes of the draft Directive. Should the Polish 'notification of the suspicion of prohibited practices' be understood as a complaint in the meaning of the draft Directive? If so, only paragraph 2 of Article 5 of the draft Directive will need to be transposed as it currently has no equivalent in the Polish APA. The analysis of the draft Directive supports the conclusion that the concept of a 'complaint' includes the 'notification' provided for in the APA. It is definitely noticeable that the draft Directive does not require Member States to equip the complainant with the rights of a party or a 'quasi-party' to administrative proceedings. Article 5(4) only obliges Member States to introduce provisions whereby the enforcement authority considers that there are insufficient grounds for acting on a complaint, it shall inform the complainant about the reasons. It does not state, however, that the complainant should have the right to appeal against such communication. Admittedly, recital 14 of the preamble to the draft Directive refers to the issue of procedural rights, but only in the context of the procedural rights of the defendant when enforcement authorities act upon complaints. Furthermore, the same recital of the preamble stipulates that the enforcement authorities should be 'able to accept and act upon complaints'. Consequently, they will not be obliged to accept a complaint and initiate proceedings (which would later be terminated after establishing that the complaint was not grounded). 
The enforcement authority needs to be given certain minimum enforcement powers inspired by best practices in Member States' existing regimes. Member States shall ensure that the enforcement authority is properly equipped and conferred with the powers (listed in Article 6(a)-(f) of the draft Directive) to:

- initiate and conduct investigations;

- require buyers and suppliers to provide all necessary information in order to carry out investigations on the prohibited trading practices;

- take a decision establishing an infringement of the prohibitions and require the buyer to terminate the prohibited trading practice, or abstain from taking any such decision, if such decision would risk revealing the identity of a complainant or disclosing any other information in respect of which the complainant considers disclosure harmful to his interests, provided that the complainant has identified that information (Article 5(3));

- impose pecuniary fines that shall be effective, proportionate and dissuasive taking into account the nature, duration and gravity of the infringement;

- publish its decisions on substance and on fines;

- inform buyers and suppliers about its activities, by way of annual reports, which shall inter alia describe the number of complaints received and the investigations initiated and closed by it; for each investigation, the report shall contain a summary description of the matter and the outcome of the investigation.

In particular, it can be expected that the powers to impose fines and to publish decisions may increase the deterrent effect. It also needs to be pointed out that based on Article 8, the powers of the relevant enforcement authority may go beyond the aforementioned list if a Member State designs to do so. At this stage of the discussed developments, the powers of the UOKiK President go even beyond Article 6(a)-(e) of the draft Directive. The UOKiK President may: start and conduct investigations, but not dawn raids (Article 16 APA); gather all necessary information from entrepreneurs (Article 14 APA); issue mentioned decisions (Article 26 APA) (except for abstaining from taking a decision for the reasons described in the draft Directive) as well as commitment decisions (Article 27 APA); impose fines of up to $3 \%$ of the annual turnover (in its accountancy meaning); as well as impose procedural fines and periodic penalty payments of up to EUR 10000 per day (Article 33-39 APA) ${ }^{50}$ The UOKiK President is also obliged to publish the decisions taken in this context (Article 30 APA). These powers are largely modelled on the

${ }^{50}$ Subject to Article 26 paragraph 3 APA, the burden of proof in administrative proceedings rests on the UOKiK President. 
powers of the NCA; only the last power - related to annual reports on cases regarding UTPs - is not explicitly provided for under Polish legislation.

In general, procedural provisions of the APA use references to the AMA so frequently that, due to literature, this legal framework could have been included into the AMA (Krasnodębska-Tomkiel, 2017, p. 688-689). In turn, the AMA refers to other statutes, including, for example the Administrative Procedure Code. Therefore, it can be said that the system of multi-level references to statutes does not foster readability of the APA (Namysłowska and Piszcz, 2017, p. 13).

\section{Conclusions}

What can be said in general about the developments described above? Some provisions of the new draft Directive give rise to doubts about how to construe them and we can expect a wide discussion thereon. In turn, the Polish APA has already been the subject of extensive critical commentary; it has been reported to have been successfully applied in only one decision so far. Certainly, both analysed documents have some defects and generate problems with their interpretation.

The scrutiny of the relevant provisions of the Polish APA and the Commission's proposal shows that the former is different from the latter on a number of issues. These include the design of their aims (protected values/ interests), the scope ratione personae, the concept of prohibited practices and the list thereof. In particular, Polish solutions regarding the scope ratione personae (not only SMEs and not only suppliers protected) seem better in terms of the effectiveness of protection against unfair trading practices.

On the other hand, there are some similarities between the two analysed sets of solutions. Similarly to the Commission's proposal, the Polish legal framework is sectorial, that is limited to food supply chains. The Polish legislature considered choosing the NCA to be the authority enforcing the prohibition of unfair B2b practice as a good solution. The powers of the enforcement authority have been regulated in a way similar to the powers of the NCA and also to the model provided for in the draft Directive, as if the Polish legislature anticipated the outcome of the Commission's works.

The legislative works in the EU institutions shall be continued. Since it seems that some problems have not been specifically addressed by the EU legal drafters (e.g. exceptions to the scope ratione personae), it would be advisable for the aforementioned points to be discussed as widely as possible. Key to the EU initiative is the acknowledgement that minimum harmonisation 
is sufficient at this stage (but it remains to be seen whether this assumption survives). The publication of the Directive will make the Polish legislature (as well as the legislatures of other Member States) launch further legislative works regarding the adjustment of the national enforcement system of the prohibition of UTPs to the minima (or above it - where allowed) and requirements of the Directive. In the course of these works, legal drafters should remember that both the minimum approach and taking advantage of the minimum harmonisation clause would provide a number of gains and losses. Legislative works should thus be accompanied by careful scrutiny of the proposals with respect to both their compatibility with EU law and the prospective effectiveness of enforcement of the prohibition of UTPs. Due consideration should be given to the issues raised in this article; it should also be ensured that legal drafters are provided with the necessary breadth of expertise. What the Polish legal framework may profit from thanks to the implementation processes is, in particular, the simplification of the tests utilised at the moment by the APA including the 'superior bargaining power test'. The issue of the powers of the enforcement authority seems much easier but even here the review of its activities with respect of EU legislation will be necessary.

\section{Literature}

Affre, J. and Skołubowicz, P. (2015). Analiza problemów związanych z regulacją relacji pomiędzy dostawcami produktów spożywczych i rolnych a sieciami handlowymi na podstawie rozwiązań zaproponowanych w projekcie ustawy PSL o nieuczciwych praktykach rynkowych. internetowy Kwartalnik Antymonopolowy i Regulacyjny, 8(4), 88-107.

Błachucki, M. (2013). Polish competition law - commentary, case law and texts. Warsaw: UOKiK.

Błachucki, M. and Jóźwiak-Górny, S. (2018). New act on contractual advantage in the trade in agricultural and food products in Poland. European Competition Law Review, 4, 152-160.

Bolecki, A. (2017), Nieuczciwe wykorzystywanie przewagi kontraktowej przez sieci handlowe względem dostawców żywności - przykłady praktyk potencjalnie zakazanych. internetowy Kwartalnik Antymonopolowy i Regulacyjny, 8(6), 60-75.

Di Marcantonio, F. and Ciaian, P. (eds) (2017). Unfair trading practices in the food supply chain: A literature review on methodologies, impacts and regulatory aspects. Luxembourg: Publications Office of the European Union.

Jurkowska-Gomułka, A. (2017). Prezes UOKiK jako organ właściwy w sprawach praktyk nieuczciwego wykorzystania przewagi kontraktowej - uwagi krytyczne. internetowy Kwartalnik Antymonopolowy i Regulacyjny, 1(6), 8-19. 
Kohutek, K. (2017). Komentarz do ustawy o przeciwdziataniu nieuczciwemu wykorzystywaniu przewagi kontraktowej. Warsaw: Lex/el.

Krasnodębska-Tomkiel, M. (2017). Kilka uwag na temat ustawy o przeciwdziałaniu nieuczciwemu wykorzystywaniu przewagi kontraktowej w obrocie produktami rolnymi i spożywczymi. In: M. Bernatt, A. Jurkowska-Gomułka, M. Namysłowska, A. Piszcz (eds), Wyzwania dla ochrony konkurencji i regulacji rynku. Warsaw: C.H. Beck.

Manteuffel, K. and Piaskowski, M. (2017). Relacja klauzuli generalnej do przykładowego katalogu nieuczciwych praktyk w ustawie o przeciwdziałaniu nieuczciwemu wykorzystywaniu przewagi kontraktowej w obrocie produktami rolnymi i spożywczymi. internetowy Kwartalnik Antymonopolowy i Regulacyjny, 1(6), 35-46.

Namysłowska, M. and Piszcz, A. (2017). Ustawa o przeciwdziataniu nieuczciwemu wykorzystywaniu przewagi kontraktowej w obrocie produktami rolnymi $i$ spożywczymi. Komentarz. Warsaw: C.H. Beck.

Piszcz, A. (2018). 'Publicisation' of civil matters in Poland. Presentation delivered at the First Conference of Visegrad Countries' Law Schools, Pázmány Péter Catholic University, Budapest (1.06.2018).

Piszcz, A. (2019). Implementing the Rules of the Damages Directive on Joint and Several Liability: The SME Derogation. In V. Bastidas, M. Iacovides, M. Strand (eds), EU Competition Litigation: Transposition and first experiences of the new regime. Oxford and Portland, Oregon: Hart Publishing (forthcoming).

Podrecki, P. (2017). Nowe regulacje w prawie konkurencji - uwagi na tle ustawy o przeciwdziałaniu nieuczciwemu wykorzystywaniu przewagi kontraktowej w obrocie produktami rolnymi i spożywczymi. In: M. Bernatt, A. Jurkowska-Gomułka, M. Namysłowska, A. Piszcz (eds), Wyzwania dla ochrony konkurencji i regulacji rynku. Warsaw: C.H. Beck.

Renda, A., Cafaggi, F., Pelkmans, J., Iamicelli, P., Correia de Brito, A., Mustilli, F., and Bebber, L. (2014). Study on the Legal Framework Covering Business-to-business Unfair Trading Practices in the Retail Supply Chain. Retrieved from: http://ec.europa.eu/ internal_market/retail/docs/140711-study-utp-legal-framework_en.pdf.

Roszak, M. and Turno, B. (2017). Przewaga kontraktowa dostawców lub nabywców towarów i jej nieuczciwe wykorzystywanie w regulacjach niemieckich i francuskich - wskazówki dla polskiej praktyki i ustawodawcy? internetowy Kwartalnik Antymonopolowy i Regulacyjny, $8(6), 17-32$.

Salitra, M. (2017). Analiza wybranych regulacji wprowadzonych ustawą o przeciwdziałaniu nieuczciwemu wykorzystywaniu przewagi kontraktowej w obrocie produktami rolnymi i spożywczymi - jakie zmiany w polskim prawie? internetowy Kwartalnik Antymonopolowy i Regulacyjny, 1(6), 126-140.

Sexton, R.J. (2017). Unfair trade practices in the food supply chain: defining the problem and the policy issues. In: F. Di Marcantonio and P. Ciaian (eds), Unfair trading practices in the food supply chain: A literature review on methodologies, impacts and regulatory aspects. Luxembourg: Publications Office of the European Union.

Sroczyński, J. (2017). Ustawa o przewadze kontraktowej: pierwsze refleksje i kontrowersje. In: M. Bernatt, A. Jurkowska-Gomułka, M. Namysłowska, A. Piszcz (eds), Wyzwania dla ochrony konkurencji i regulacji rynku. Warsaw: C.H. Beck.

Stawicki, A. (2017). The Polish Competition Authority Gains New Powers to Fight Unfair Practices in the Food Industry. At: http://kluwercompetitionlawblog.com/2017/01/19/ 
the-polish-competition-authority-gains-new-powers-to-fight-unfair-practices-in-thefood-industry/.

Szwedziak-Bork, I. (2017). Entia non sunt multiplicanda praeter necessitatem, czyli o potrzebie uchwalenia ustawy o przeciwdziałaniu nieuczciwemu wykorzystywaniu przewagi kontraktowej w obrocie produktami rolnymi i spożywczymi. internetowy Kwartalnik Antymonopolowy i Regulacyjny, 8(6), 108-114.

UOKiK (2017). 100 days of the act on the unfair use of contractual advantage. At: https:// uokik.gov.pl/news.php?news_id=13603. 